\title{
A Comparative Study on the Effectiveness of Human Resource Professionals in Pakistan and Malaysia
}

\author{
Mohmad Yazam Sharif ${ }^{1}$, Aqeel Ahmad ${ }^{2}$ and Abdul Rashid Kausar ${ }^{2}$ \\ ${ }^{1}$ Sultan Idris Education University (UPSI), Tanjong Malim, Perak, Malaysia \\ ${ }^{2}$ School of Business and Economics, University of Management and Technology \\ C-II Johar Town, Lahore, Pakistan
}

\begin{abstract}
The aim of this empirical paper was to show the comparison between the effectiveness of Human Resource (HR) professionals and the organizational factors (namely, leadership, organizational support and reward system), based on a study on the HR professionals in two private universities - A university(AU) in Pakistan and B university(BU) in Malaysia. Both are private universities which have multi disciplinary business, technology and education related programs. Both institutions own sophisticated systems (both humans and technology). Consequently, the human resource management (HRM) practices in AU and BU could be said to be quite advanced because of this. The approach employed in this study was to gather data on the human resource professionals from the perspectives of knowledge workers (the faculty members) in the two institutions. The data was collected through survey questionnaires which were distributed to $110 \mathrm{AU}$ and 150 to BU knowledge workers. However, 73 questionnaires were returned from $\mathrm{AU}$ (response rate $70 \%$ ) while only 66 questionnaires were obtained from $\mathrm{BU}(44 \%$ response rate). The study shows that there was a correlation between leadership and HR effectiveness in AU (0.58) and also in BU (0.699). The correlation between organizational support and HR effectiveness was low in AU (0.49) but strong in BU (0.673). The correlation between reward system and HR effectiveness was found to be fair for both AU (0.53) and BU (0.51). For $\mathrm{AU}$, the weakest predictor was organizational support $(0.49)$ while for $\mathrm{BU}$, it was the reward system (0.51).
\end{abstract}

Keywords: HR professional, human resource management, knowledge workers, knowledge management

\section{Introduction}

This paper is on Human Resource professionals' effectiveness in managing knowledge workers. Knowledge worker, a concept used in 1959 by Peter Drucker, the well-known American management guru, only became prominent with the emergence of the knowledge management concept in the early 1990s (Alavi \& Leidner, 2001; Kakabadse \& Kakabadse, 2003; Scarbrough \& Swan, 2002). Knowledge workers in today's workforce are individuals who are valued for their ability to act and communicate with knowledge within a specific subject area. They will often advance the overall understanding of that subject through focused analysis, design and/or development. They use research skills to define problems and to identify alternatives. Fueled by their expertise and insight, they work to solve those problems, in an effort to influence company decisions, priorities and strategies. Knowledge workers may be found across several information technology (IT) roles. However, they can also be found among

Copyright (C) 2011 Mohmad Yazam Sharif, Aqeel Ahmad and Abdul Rashid Kausar. This is an open access article distributed under the Creative Commons Attribution License unported 3.0, which permits unrestricted use, distribution, and reproduction in any medium, provided that original work is properly cited. Contact author: Mohmad Yazam Sharif, e-mail: yaazaam@yahoo.com 
teachers (schools and universities), librarians, lawyers, architects, physicians, nurses, engineers and scientists. As businesses increase their dependence on IT, the fields in which knowledge workers are operating will ultimately expand.

At the same time, with the coming of knowledge management (KM) into organizations, people management or human resource management (HRM) of employees is no longer the same (Becker \& huselid, 2006). KM and HRM are two different concepts but they are said to be somehow connected (Currie \& Kerrin, 2003; Hislop, 2003; Kakabadse \& Kakabadse, 2003; Salleh, Y. \& Goh, 2002; Scarbrough \& Swan, 2002; Soliman \& Spooner, 2000). For example, in serviceoriented organizations, the ability of human resource professionals to manage the knowledge within employees (the knowledge workers) is slowly being recognized as crucial to the sustainability or survival of the organizations (Deem, 2004; Soliman \& Spooner, 2000).

One of the important institutions of modern economy is the universities. As mentioned earlier, university teachers (or lecturers) are also regarded as knowledge workers. The HR professionals in universities (like other institutions whether firms or governmental bodies) have to manage these knowledge workers. Otherwise they may be losing talented people to their competitors. Have they been performing well? Are they effective in managing the knowledge workers?

The notion of managerial effectiveness has been of interest to researchers since the 1960s (Fisher, Merron \& Torbert; 1987; Mahoney, Jerdee \& Nash, 1960; Miner, 1978; Morse \& Wagner, 1978; Worsfold, 1989). They have focused on various issues such as measuring the managerial effectiveness, examining the process of ensuring managerial effectiveness and building models of managerial effectiveness. In general, they were investigating the capability of managers in managing organizational resources.
However, since the 1990s, researchers began studying one part of management, which was slowly coming into its own human resource management (HRM). Human resource professionals or managers were studied to determine whether they were effective managers of human resources in their respective organizations (Jian, Paul, Minston \& Wright, 2006; Mitsuhashi, Hyern, Wright \& Chua, 2000; Richard \& Johnson, 2001; Wright, McMahan, McCormick \& Sherman, 1998; Wight, McMahan, Snell \& Gerhart, 2001). Most of them studied specific factors in relation to HR effectiveness. For example, Wright et al. (2001) compare human resource (HR) and line executives' evaluation of the effectiveness of HR functions in term of its service delivery, roles and contributions to firms. The survey respondents were $44 \mathrm{HR}$ and 59 line executives from 14 companies. These studies failed to look at the contextual factors which could affect the effectiveness of HR executives or professionals in their work.

Richard and Johnson (2001) seem to be the exception. They used a resource-based view of the firm to examine the effectiveness of human resource experts. They looked at the role of contextual factors on HR effectiveness. They used different terms but generally the factors can be attributed to the leaders (or CEOs), organizational support and reward system (Drew \& Bensley, 2001).

\section{HR Effectiveness and Knowledge Work in the Knowledge Economy}

For now and in the coming years, HR professionals have the difficult task of dealing with and managing 'knowledge workers' in organizations (Jian et al., 2006; Misuhashi et al., 2000). It has been realized by corporate leaders and educational leaders that employees in many organizations are slowly becoming 'knowledge workers' in line with the advancement of information and communication technology (ICT) (Colbert, 2004; Richard \& Johnson, 2001). The 
increasing numbers of researchers who have studied knowledge work and knowledge worker in the emerging global knowledge economy are a reflection of this phenomenon (Kleinman \& Vallas, 2001; Kubo \& Saka, 2002, Tyman \& Stumpf, 2003).

In line with this development, human resource management (HRM) functions in organizations are changing. HRM work in the knowledge economy includes both activities that overlap with other traditional business functions (for instance, finance, marketing, strategy) and some that are nontraditional (for instance, knowledge management, intellectual capital, and organizational memory)(Currie \& Kerrin, 2003). For this reason, HRM is no longer simply focused on "managing people" in the conventional way. HRM is now responsible for managing the capabilities that people create and the relationships that people must develop (Hall \& Hall, 2003). HRM roles, thus, have to be more proactive than before in line with the new demands in the environment. Rogoski (1999) argues that "Knowledge workers use their intellect to convert their ideas into products, services, or processes".

According to the Australian Bureau of Statistics (ABS) (2002), "Knowledge workers are defined as those classified as managers and administrators, professionals and associate professionals in the Australian Standard Classifications of Occupations (ASCO). This indicates a strong ability to create and use knowledge throughout the economy. Professionals and associate professionals, in particular, have steadily increased as a proportion of the labour force over the last five years, increasing from 28\% in 1997 to $30 \%$ in 2003. The fastest-growing occupations have tended to be in knowledge work, including professionals and paraprofessionals". The rise of the knowledge workers in the employment market worldwide since the early 1990s is beginning to shape the nature of jobs in the world for the $21^{\text {st }}$ century (OECD, 2001). The need for human resource professionals to manage these knowledge workers effectively in various organizations is growing by the day.

\section{Methodology}

\section{Research Framework}

The independent variables in this research are Leadership / CEO, Organizational Support and Reward System. The reasons for selecting these factors as the independent variables were that past researchers (e.g. Drew \& Bensley, 2001; Richard \& Johnson, 2001) believed that contextual factors (like leadership, organizational support and reward system) play important roles in influencing HR professionals' effectiveness. On opposite end is the HR professionals' effectiveness the dependent variable. There are three constructs for measuring the effectiveness of the human resource professionals' roles (i.e. recruiting, appraisal and training) (Drew \& Bensley, 2001). These constructs are considered simple to observe and measure by some researchers (Jian et al., 2006; Wright et al., 1998).The relationships between the variables for this study are depicted in Figure 1.

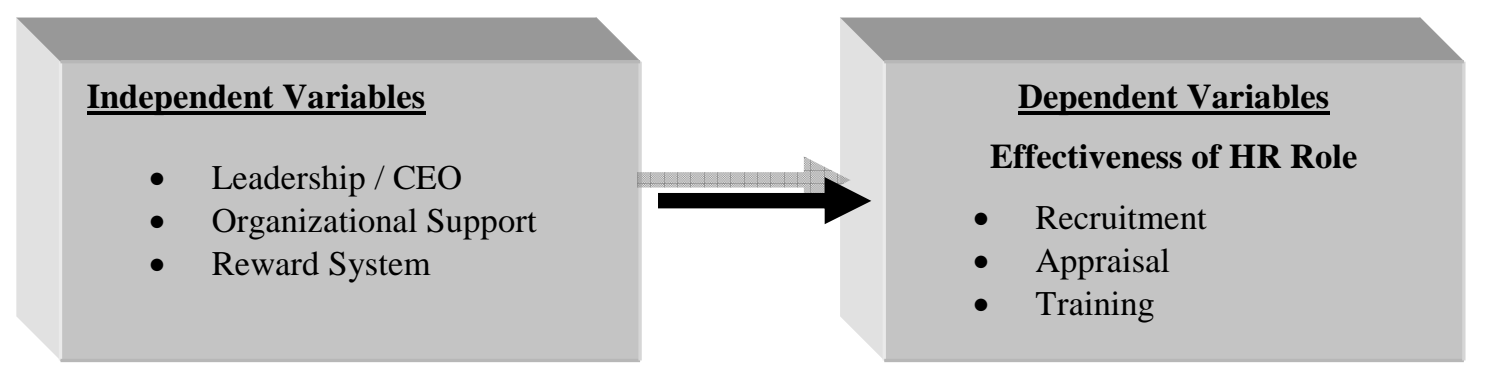

Figure 1 The Research Framework 


\section{Operational Definitions of the Research Variables}

The human resource effectiveness was the dependent variable and was measured by the ability of HR professionals to play three roles - recruitment, employee performance appraisal and training.

The three independent variables were leadership, organizational support and reward system (Table 2). The leadership variable covers the decisions and behaviors of organizational leaders which affect the HR professionals' performance. Next is organizational support. This factor covers resources, infrastructure and moral support that the organization gives to the Human Resource professionals. Lastly is the reward system. This factor covers both monetary as well as non-monetary benefits to the Human Resource professionals which can serve to motivate them to perform better.

\section{Research Design and Limitations of the Study}

This was a cross-cultural comparative study on two private universities (Carayannis, Evans \& Hanson, 2003; Ramburuth \& McCormick, 2001; Spector, Cooper \& Poelmans, 2004). This type of study is said to be beneficial in the enhancement of our understanding of the same phenomenon in two different settings. But as in any other research, this study has some limitations. The focus of this study was made only on AU in Pakistan and BU in Malaysia - two private universities. Thus generalization of the findings to other situations could be limited.

\section{The Study Instrument and the Questionnaire Design}

This study had utilized the survey questionnaire as the instrument for data collection.

The survey questionnaire consisted of three parts as depicted in the following Table 1.

Table 1 The Questionnaire Design

Questionnaire Parts Descriptions

PART 1

PART 11

PART 111

Respondent background contained 9 questions.

The effectiveness of human resource professional in AU contained nine questions.

Factors influencing the human resource professionals' effectiveness. This part contained three variables, Leadership, Organizational Support and Reward System. The questions contained all these variables were, six, nine and eight, respectively.

The factors that could influence the HR professionals' effectiveness (leadership, organizational support and reward system) are shown in Table 2. 
Table 2 Factors Influencing the HR Professionals' Effectiveness

\begin{tabular}{ll}
\hline Variables & Operational Definition \\
\hline Leadership & $\begin{array}{l}\text { Decisions and behaviors of } \\
\text { organizational leaders have } \\
\text { been claimed to affect } \\
\text { employees' performance. }\end{array}$ \\
& \\
Organizationa & $\begin{array}{l}\text { One of the important factors } \\
\text { that has been said to affect } \\
\text { employees' performance is } \\
\text { organizational support such } \\
\text { as resources, } \\
\text { infrastructures and moral } \\
\text { support. }\end{array}$
\end{tabular}
Items

Top Management strongly supports HR functions.

Top Management is really interested in the growth of the organization.

Top Management generally complements the efforts initiated by HR Professionals.

Top Management has created a conducive working environment for HR Professionals.

Top Management usually gets the results they want through the HR Professionals.

Top Management has hired a skillful group of HR Professionals.

HR department has enough staff for their work.

HR department has enough budget to facilitate the employees.

HR department has the latest technology for work.

HR department has the empowerment to implement the policy decision.

HR department has a good relationship with other academic support departments.

HR department has a good relationship with the academic departments.

HR department has been provided with adequate training facilities.

HR department has been provided with adequate training budget.

HR department has been given adequate operational budget.

Reward The reward system in an System organization is considered by many as the most important factor which affects the performance of employees. Reward systems can give people the motivation to undertake desired actions.

HR department does not have enough financial resources to give attractive rewards to the faculty.

The salary package administered by HR department is very competitive.

The Salary package for faculty by HR department is above the market rate for the Pakistan education sector.

The benefits package for faculty is also very competitive.

The total reward package attracts good and talented faculty.

The total reward package ensures good faculty are retained.

HR department changes (time to time) the reward system policy according to the new economic situation.

HR department gives rewards according to the performance of the faculty.

The scale of these items is: 1- Strongly disagree: 2- Disagree: 3- Neutral: 4-Agree:

5- Strongly Agree: 


\section{The Reliability Test}

In order to ensure the reliability of all dimensions of each variable in this case study, the reliability test for scales was conducted using Cronbach's Alpha. The internal consistency was calculated using the Cronbach's Alpha approach to determine whether the instrument was reliable. As depicted in the following Table 3 , the reliability values could be considered acceptable.

Table 3 Reliability Coefficients of Dimensions

\begin{tabular}{|l|l|l|l|}
\hline Factors & $\begin{array}{l}\text { Number of } \\
\text { Items }\end{array}$ & $\begin{array}{l}\text { Cronbach's } \\
\text { Alpha for AU }\end{array}$ & $\begin{array}{l}\text { Cronbach's } \\
\text { Alpha for BU }\end{array}$ \\
\hline & & & \\
The Effectiveness of HR Professionals & & & \\
Factors: & 8 & 0.69 & 0.64 \\
& 23 & 0.77 & 0.91 \\
Leadership & 6 & 0.70 & 0.76 \\
Organizational Support & 9 & 0.60 & 0.78 \\
Reward System & 8 & 0.76 & 0.89 \\
\hline
\end{tabular}

Usually, the Cronbach's Alpha values for the items should be more than 0.6 (Sekaran \& Bougie, 2010). Table 3 shows that the items to be examined had fulfilled the criteria.

\section{The Survey Response Rate}

A total of 110 questionnaires were distributed in AU (Pakistan) and 150 were distributed in BU (Malaysia). During this phase, explanation was made to clarify the purpose of this study to the faculty members of the $\mathrm{AU}$ and $\mathrm{BU}$. Table 4 shows that the survey in AU had produced 70 per cent response rate while the survey in $\mathrm{BU}$ had achieved a response rate of 33 per cent. The response rate for $\mathrm{AU}$ was probably better as the researchers were based in AU. The BU survey, however, was done from a distant and the researchers depended solely on the willingness of the respondents to return the questionnaires.

Table 4 Survey Questionnaires Responses

\begin{tabular}{|l|l|l|l|l|}
\hline & Total & $\begin{array}{c}\text { Percentage } \\
\text { (\%) }\end{array}$ & Total & $\begin{array}{c}\text { Percentage } \\
\text { (\%) }\end{array}$ \\
\hline Distributed Questionnaires & $\mathbf{A U}$ & 110 & $\mathbf{B U}$ & 100 \\
Collected Questionnaires & 77 & 70 & 150 & 100 \\
Uncollected Questionnaires & 33 & 30 & 66 & 44 \\
\hline
\end{tabular}

\section{Data Analysis}

The survey questionnaire data collected from the faculty members of the $\mathrm{AU}$ and $\mathrm{BU}$ were analyzed. Data from questionnaire were coded and analyzed using Statistical Software Package for Social Science (SPSS) Version 16. For this paper, only the correlation findings were presented.

\section{Research Findings and Discussion}

\section{Demographic of the Respondents}

The background of the respondents who had responded to the survey is shown in Table 5. The respondents' profiles are viewed in terms of five dimensions - the respondents' titles, their highest 
qualifications, their age groups, their gender and their nationality. In terms of nationality, all respondents are Pakistanis while for BU, the respondents consisted of mixed nationalities with Malaysians being the majority ( $82 \%)$. In terms of gender, the males in $\mathrm{AU}$ and $\mathrm{BU}$ form the largest group. In terms of age, the majority of respondents in both $\mathrm{AU}$ and $\mathrm{BU}$ are young (between 21 and 40). Most respondents from AU and BU held masters' degrees (69 $\%$ and $91 \%$ respectively). In terms of the respondents' titles, most respondents in AU and BU were in the lecturer category (42\% and $88 \%$ respectively).

Table 5 Demographic Profile of the Respondents in UMT and MMU

\begin{tabular}{|c|c|c|c|c|c|}
\hline $\begin{array}{l}\text { Demographic } \\
\text { Profile }\end{array}$ & & $\begin{array}{l}\text { Frequenc } \\
\text { y } \\
\quad \mathrm{AU} \\
\end{array}$ & $\begin{array}{c}\text { Percentag } \\
\text { e (\%) }\end{array}$ & $\begin{array}{c}\text { Frequency } \\
\text { BU }\end{array}$ & $\begin{array}{c}\text { Percentage } \\
\text { (\%) }\end{array}$ \\
\hline Title & $\begin{array}{l}\text { Professor } \\
\text { Associate Professor } \\
\text { Assistant Professor } \\
\text { Lecturer }\end{array}$ & $\begin{array}{l}9 \\
5 \\
31 \\
32\end{array}$ & $\begin{array}{l}11.7 \\
6.5 \\
40.3 \\
41.6\end{array}$ & $\begin{array}{l}- \\
1 \\
7 \\
58\end{array}$ & $\begin{array}{l}- \\
1.5 \\
10.6 \\
87.9\end{array}$ \\
\hline $\begin{array}{l}\text { Highest } \\
\text { Qualification }\end{array}$ & $\begin{array}{l}\text { Ph. D. } \\
\text { Masters } \\
\text { Other }\end{array}$ & $\begin{array}{l}13 \\
53 \\
11\end{array}$ & $\begin{array}{l}16.9 \\
68.8 \\
14.3\end{array}$ & $\begin{array}{l}4 \\
60 \\
2\end{array}$ & $\begin{array}{l}6.1 \\
90.9 \\
3.0\end{array}$ \\
\hline Age & $\begin{array}{l}21-30 \\
31-40 \\
41-50 \\
51-60 \\
61 \text { and above }\end{array}$ & $\begin{array}{l}21 \\
31 \\
13 \\
5 \\
7\end{array}$ & $\begin{array}{l}27.3 \\
40.3 \\
16.9 \\
6.5 \\
9.1\end{array}$ & $\begin{array}{l}26 \\
32 \\
6 \\
2 \\
-\end{array}$ & $\begin{array}{l}39.4 \\
48.5 \\
9.0 \\
3.0 \\
-\end{array}$ \\
\hline Gender & $\begin{array}{l}\text { Male } \\
\text { Female }\end{array}$ & $\begin{array}{l}63 \\
14\end{array}$ & $\begin{array}{l}81.8 \\
18.2\end{array}$ & $\begin{array}{l}40 \\
26\end{array}$ & $\begin{array}{l}60.6 \\
39.4\end{array}$ \\
\hline Nationality & $\begin{array}{l}\text { Pakistani } \\
\text { Bangladeshi } \\
\text { Sri Lanka } \\
\text { Iranian } \\
\text { Malaysian }\end{array}$ & 110 & 100.0 & $\begin{array}{l}3 \\
5 \\
1 \\
1 \\
54\end{array}$ & $\begin{array}{l}4.5 \\
7.5 \\
1.5 \\
1.5 \\
81.8\end{array}$ \\
\hline
\end{tabular}

Correlation of $A U$ and $B U$ and Their Related Variables

Correlation analysis a technique to determine the degree to which variables are linearly related (Levin \& Rubin, 1991). Table 6 shows the correlation variables for AU while Table 7 shows the correlation variables for BU.

Table 6 and Table 7 show all the variables studied in the two universities, namely, Human Resource (HR) Effectiveness, Organizational Support, Reward System and Leadership. The first variable, HR Effectiveness, was the dependent variable where as the next three variables were independent variables. At the significance level of 0.01 the study shows that there was a correlation between leadership and HR effectiveness for AU (0.58) and for BU (0.69). There was also correlation between organizational support and HR effectiveness as the values were found to be 0.49 for AU and 0.67 for BU. Lastly, there was correlation between reward system and HR effectiveness as the values were found to be 0.53 for $\mathrm{AU}$. 
Table 6 Correlation of the Variables from AU

\begin{tabular}{|c|l|l|l|l|}
\hline Variables & \multicolumn{1}{|c|}{ (a) } & \multicolumn{1}{|c|}{ (b) } & \multicolumn{1}{c|}{ (c) } & \multicolumn{1}{c|}{ (d) } \\
\hline $\begin{array}{c}\text { (a) Human Resource } \\
\text { Effectiveness }\end{array}$ & 1 & $.578^{* *}$ & $.490^{* *}$ & $.525^{* *}$ \\
\hline (b) Leadership & $.578^{* *}$ & 1 & $.394^{* *}$ & $.361^{* *}$ \\
\hline $\begin{array}{c}\text { (c) Organizational } \\
\text { Support }\end{array}$ & $.490^{* *}$ & $.394^{* *}$ & 1 & $.361^{* *}$ \\
\hline (d) Reward System & $.525^{* *}$ & $.361^{* *}$ & $.361^{* *}$ & 1 \\
\hline
\end{tabular}

Table 7 Correlation of the Variables from BU

\begin{tabular}{|c|l|l|l|l|}
\hline Variables & \multicolumn{1}{|c|}{ (a) } & (b) & \multicolumn{1}{|c|}{ (c) } & (d) \\
\hline $\begin{array}{c}\text { (a) Human Resource } \\
\text { Effectiveness }\end{array}$ & 1 & $.699^{* *}$ & $.673^{* *}$ & $.512^{* *}$ \\
\hline (b) Leadership & $.699^{* *}$ & 1 & $.731^{*}$ & $.453^{*}$ \\
\hline $\begin{array}{c}\text { (c) Organizational } \\
\text { Support }\end{array}$ & $.673^{* *}$ & $.731^{*}$ & 1 & $.554^{* *}$ \\
\hline (d) Reward System & $.512^{*}$ & $.453^{*}$ & $.554^{* *}$ & 1 \\
\hline
\end{tabular}

So from the above correlation results between independent and dependent variables, it was concluded that there was evidence of high correlation between leadership and HR effectiveness for both AU (0.58) and BU (0.69) and there was an indication of low correlation between organizational support and HR effectiveness for $\mathrm{AU}$ (0.49) but strong correlation between organizational support and HR effectiveness for BU (0.67).

\section{Conclusion}

This comparative study serves as a source of baseline data for researchers who are interested in investigating the issue of human resource effectiveness and its relationships with some predictors in developing countries. The predictors chosen for the study were leadership, organizational support and reward system. They were chosen for bases started by Drew \& Bensley (2001) and Richard \& Johnson, (2001). The samples comprised two private universities operating in two developing countries - Pakistan and Malaysia. The background of the two universities were different - AU in Pakistan, a homogenous country and BU in Malaysia, a heterogeneous country. Yet both universities share something in common, i.e. both are private universities with high autonomy in decision-making.

The study shows that there was a correlation between leadership and HR effectiveness in $\mathrm{AU}$ (0.58) and also in $\mathrm{BU}$ (0.69). This finding indicates that the role of an organization's leadership can be an important factor in influencing $\mathrm{HR}$ professionals' effectiveness. The correlation between organizational support and HR effectiveness was low in AU (0.49) but strong in BU (0.67). This finding indicates there is a difference between the Pakistani setting (where AU is) and the Malaysian setting (where BU is). The resources available for $\mathrm{AU}$ and $\mathrm{BU}$ were different. The correlation between the reward system and HR effectiveness was found to be fair for both $\mathrm{AU}(0.53)$ and $\mathrm{BU}$ (0.51). For $\mathrm{AU}$, the weakest predictor was organizational support (0.49) while for $\mathrm{BU}$, it was the reward system (0.51). For AU, the HR professionals' effectiveness 
seems to be related to leadership and the reward system. This situation was similar to the results found by Bowers and Seashore (1966) even though they studied organizational effectiveness rather than HR professionals' effectiveness. On the other hand, for BU, the HR professionals' effectiveness was related more to the contributions of its leaders and organizational support. The reward system is a non-factor. The situation for BU was somewhat similar to Bolman and Deal's (1991) conceptualization and findings.

\section{Future Research}

The researchers have attempted to study human resource management (HRM) and knowledge worker issues. This is a challenging area to pursue as HRM roles are changing rapidly in line with the changing environment particularly in the context of global knowledge economy (Dickman, Muller-Carmen \& Kelliher, 2009; Teo, Lakhani, Brown \& Malmi, 2008). More research should be done in future in this area.

More survey on the private higher education institutions in Pakistan as well as in Malaysia should be undertaken as this will give interested parties a broader picture of the knowledge worker and HR professionals in the Pakistani and Malaysian private higher education sectors.

Other comparative surveys of private higher education institutions in South Asia (comprising Pakistan, Bangladesh, India and Sri Lanka) and South East Asia (comprising, Singapore, Indonesia, Thailand, the Philippines and Malaysia) should also be done. This will give us a more comprehensive view of the knowledge workers and HR professionals' performance in these two regions. Lessons learnt from these studies can be more useful for applications in other similar contexts and regions worldwide.

\section{References}

Alavi, M. \& Leidner, D. E. (2001). "Review: Knowledge Management and Knowledge Management Systems: Conceptual
Foundations \& Research Issues," MIS Quarterly, 25(1). 107 - 136.

Australian Bureau of Statistics (2002). "Measuring a Knowledge-Based Economy and Society: An Australian Framework," http://www.abs.gov.au/Ausstarts/abs@.ns f/Lookup/DEFCCF3758F041E2CA256C220 0831EE3

Becker, B. E. \& Huselid, M. A. (2006). "Strategic Human Resource Management: Where Do We Go From Here?" Journal of Management, 32, 898 - 925.

Bolman, L. G. \& Deal, T. E. (1991). "Leadership and Management Effectiveness," Human Resource Management, 30(4). 509 - 534.

Bowers, D. G. \& Seashore, S. E. (1966). "Predicting Organizational Effectiveness with a Four-Factor Theory of Leadership," Administrative Science Quarterly, 11(2). $253-263$.

Carayannis, E. G., Evans, D. \& Hanson, M. (2003). "A Cross Cultural Learning Strategy for Entrepreneurship Education: Outline of Key Concepts and Lessons Learned From a Comparative Study of Entrepreneurship Students in France and the US," Technovation, 23(9). 757 - 771 .

Caudron, S. (2000). "Building Better Bosses," Workforce, May, 33-39.

Colbert, B. A. (2004)."The Complex Resource-Based View: Implications for Theory and Practice in Strategic Human Resource Management," Academy of Management Review, 29(3). 341 - 358.

Currie, G. \& Kerrin, M. (2003). "Human Resource Management and Knowledge Management" Enhancing Knowledge Sharing in a Pharmaceutical Company," The International Journal of Human Resource Management, 14(6). 1027 - 1045.

Deem, R. (2004). "The knowledge Worker, the Manager-Academic and the Contemporary UK University," Financial Accountability and Management, 20(2). 107 $-128$. 
Dickman, M., Muller-Carmen, M. \& Kelliher, C. (2009). "Exploring Standardization and Knowledge Networking Processes in Transnational Human Resource Management," Personnel Review, 38(1). 5 25.

Drew, G. \& Bensley, L. (2001). “Managerial Effectiveness for A New Millennium in the Global Higher Education Sector," Higher Education in Europe, 26(1). 61 - 68.

Fisher, D., Merron, K. \& Torbert, W. R. (1987). "Human Development and Managerial Effectiveness," Group Organization Management, 12(3). 257 273.

Han, J., Chou, P., Chao, M. \& Wright, P. M. (2006). "The Human Resource Competencies -Human Resource Effectiveness Link: A Study in Taiwanese High-Tech Companies," Human Resource Management, 45(3). 391 - 406.

Harrison, N. (2000). 'Improving Employee Performance,' London: Kogan Page.

Hislop, D. (2003). "Linking Human Resource Management and Knowledge Management via Commitment: A Review and Research Agenda," Employee Relations, 25(2). $182-202$.

Kakabadse, N. K., Kakabadse, A. \& Kouzmin, A. (2003). "Reviewing the Knowledge Management literature towards a Taxonomy," Journal of Knowledge Management, 7(4). 75 - 91.

Kleinman, D. L. \& Vallas, S. P. (2001). "Science, Capitalism and the Rise of the 'Knowledge Worker': The Changing Structure of Knowledge Production in the US," Theory \& Society, 30(4). 451 - 492.

Kubo, I. \& Saka, A. (2002). “An Inquiry into the Motivations of Knowledge Workers in the Japanese Financial Industry," Journal of Knowledge Management, 6(3). 262 - 271.

Lengnick-Hall, M. L. \& Lengnick-Hall, C. A. (2003). Human Resource Management in the Knowledge Economy, Boston: BerrettKoehler Publishers, Inc.
Levin, I. R. \& Rubin, S. D. (1991). Statistics for Management (5th ed.), New York: Prentice Hall USA.

Mahoney, T. A., Jerdeee, T. H. \& Nash, A. N. (1960). "Predicting Managerial Effectiveness," Personnel Psychology, 13(2). $147-163$.

Mathis, R. L. \& Jackson, J. H. (2004). 'Human Resource Management,' Singapore: Thomson.

Mello, J. A. (2002). 'Strategic Human Resource Management,' Boston: SouthWestern, Thomson Learning.

Miner, J. B. (1978). "Twenty Years of Research on Role-Motivation Theory of Managerial Effectiveness," Personnel Psychology, 31(4). 739 - 760.

Mitsuhashi, H., Park, H. J., Wright, P. M. \& Chua, R. S. (2000). "Line and HR Executives' Perceptions of HR Effectiveness in Firms in the People's Republic of China," The International Journal of Human Resource Management, 11(2). 197 - 216.

Morse, J. J. \& Wagner, F. R. (1978). "Measuring the Process of Managerial Effectiveness," Academy of Management Journal, 21(1). 23 - 35.

Noe, R. A., Hollenbeck, J. R., Gerhart, B. \& Wright, P. M. (2003). 'Human Resource Management,' New York: McGraw Hill.

OECD (2001). “The New Economy: Beyond the Hype," Paris: OECD.

Ramburuth, P. \& McCormick, J. (2001). "Learning Diversity in Higher Education: A Comparative Study of Asian International and Australian Students," Higher Education, 42(3). $333-350$.

Richard, O. C. \& Johnson, N. B. (2001). "Strategic Human Resource Management Effectiveness and Firm Performance," The International Journal of Human Resource Management, 12(2). 299 - 310. 
Rogoski, R. R. (1999). 'Knowledge Workers Top Company Assets,' Triangle Business Journal, 19, January, 21 - 26.

Scarbrough, H. \& Swan, J. (2002). "Explaining the Diffusion of Knowledge Management," British Journal of Management, 12(1). 3 - 12.

Sekaran, U. \& Bougie, R. (2010) 'Research Methods for Business,' Chichester: John Wiley \& Sons.

Soliman, F. \& Spooner, K. (2000). "Strategies for Implementing Knowledge Management: Role of Human Resource Management," Journal of Knowledge Management, 4(4). 337 - 345.

Spector, P. E., Cooper, C. L., Poelmans, S., Allen, T. D., O'Driscoll, M., Sanchez, J. I., Siu, O. L., Dewe, P., Hart, P., Lu, L. (2004). “A Cross-National Study of Work Family Stressors, Working Hours and Well-Being: Chinese and Latin American versus the Anglo World," Personnel Psychology, 57(1). $119-142$.

Teo, S. T. T., Lakhani, B., Brown, D. \& Malmi, T. (2008). "Strategic Human Resource Management and Knowledge Workers," Management Research News, 31(9). 683 696.

Torrington, D. \& Hall, L. (1998). 'Human Resource Management (4th ed.),' London.

Tsui, A. S. \& Ohlott, P. (1988)."Multiple Assessment of Managerial Effectiveness: Interrater Agreement and Consensus in Effectiveness Models," Personnel Psychology, 41(4). $779-803$.

Tyman, W. G. \& Stumpf, S. A. (2003). “Social Capital in the Success of Knowledge Workers," Career Development International, 8(1). 12 - 20.

Worsfold, P. (1989). "Leadership and Managerial Effectiveness in the Hospitality Industry," International Journal of Hospitality Management, 8(2). 145 - 155.

Wright, P. M., McMahan, G. C., McCormick, B. \& Sherman, W. S. (1998). "Strategy, Core
Competence and Human Resource Involvement as Determinants of Human Resource Effectiveness and Refinery Performance," Human Resource Management, 37(1). 17 - 29.

Wright, P. M., McMahan, G. C., Snell, S. A. \& Gerhart, B. (2001). "Comparing Line and Human Resource Executives' Perceptions of Human Resource Effectiveness: Services, Roles and Contributions," Human Resource Management, 40(2). 111 - 123.

Yahya, S. \& Goh, W.-K. (2002). "Managing Human Resources Toward Achieving Knowledge Management," Journal of Knowledge Management, 6(5). 457 - 468. 